\title{
IMPLEMENTASI PROGRAM BANTUAN LANGSUNG TUNAI DANA DESA SEBAGAI UPAYA PENANGANAN PANDEMI CORONA VIRUS DISEASE (COVID-19) DI DESA PRAJEKAN LOR KABUPATEN BONDOWOSO
}

\author{
THE IMPLEMENTATION OF VILLAGE FUND CASH DIRECT \\ ASSISTANCEAS EFFORT TO HANDLE THE CORONA VIRUS DISEASE \\ (COVID-19) PANDEMICAT PRAJEKAN LOR VILLAGE BONDOWOSO \\ REGENCY
}

\author{
Usrotul Hasanah $^{1}$, Yeni Febriyana Putri ${ }^{2}$ ) \\ ${ }^{1,2}$ Administrasi Publik, Fakultas Ilmu Sosial dan Politik \\ Universitas Abdurachman Saleh Situbondo \\ ${ }^{1}$ Email: uusstbondo@gmail.com
}

\begin{abstract}
ABSTRAK
Penelitian ini bertujuan untuk mengetahui implementasi Bantuan Langsung Tunai Dana Desa di Desa Prajekan Lor Kabupaten Bondowoso dengan mengacu pada peraturan yang digunakan sebagai landasan pelaksanaan program oleh Desa Prajekan Lor yakni Peraturan Kepala Desa Nomor 188 Tahun 2020 Tentang Penetapan Penerima Bantuan Langsung Tunai Dana Desa.Metode yang digunakan dalam penelitian ini kualitatif deskriptif. Sumber data dalam penelitian ini adalah primer dan sekunder yakni wawancara, dokumentasi serta observasi. Peneliti menggali informasi dan data dengan wawancara kepada informan yang telah ditentukan, informan tersebut adalah orang-orang yang terlibat langsung dalam penyelenggaraan Program BLTDD. Sedangkan analisis datanya adalah analisis interaktif. Hasil penelitian menunjukkan bahwa pelaksanaan Program Bantuan Langsung Tunai Dana Desa di Desa Prajekan Lor mengenai penerima dan besaran nominal bantuan sosial yang diberikan sesuai dengan peraturan yang berlaku yakni Masyarakat Miskin terdampak Covid-19 baik secara langsung maupun tidak langsung, tidak menerima bantuan sosial lainnya seperti PKH, BPNT dan Prakerja dengan nominal yang diterima sebesar Rp 600.000 selama 3 bulan setiap bulan secara tunai. Artinya dalam segi kriteria dan nominal telah terimplementasi sesuai peraturan. Sedangkan ketentuan mengenai waktu penyaluran terdapat perbedaan, dimana masa penyaluran selisih 1 (satu) bulan dari waktu yang ditentukan. Dalam peraturan disebutkan bahwa penyaluran terhitung sejak bulan April 2020 sedangkan penyaluran terlaksana pada bulan Mei 2020. Hal ini berarti dalam segi waktu penyaluran belum terimplementasi sesuai peraturan yang ada.
\end{abstract}

Kata kunci: Implementasi, Kebijakan, Bantuan langsung tunai dana desa

This study aims to determine the implementation of Village Fund Cash Direct Assistance in PrajekanLor Village, Bondowoso Regency with reference to the regulations used as the basis for program implementation by PrajekanLor Village, namely Village Head Regulation Number 188 of 2020 concerning Determination of Recipients of Village Cash Direct Assistance.The method used in this research is descriptive qualitative. Sources of data in this study are primary and secondary, namely interviews, documentation and observation. Researchers dig up information and data by interviewing predetermined informants, these informants are people who are directly involved in the implementation 
P-ISSN 2580 - 7781

E-ISSN $2615-3238$

of the BLTDD Program. The data analysis is interactive analysis.The results showed that the implementation of the Village Fund Direct Cash Assistance Program in PrajekanLor Village regarding the recipients and the nominal amount of social assistance provided in accordance with applicable regulations, namely the Poor affected by COVID-19 either directly or indirectly, did not receive other social assistance such as PKH,BPNT and Preemployment with a nominal received of $R p 600.000$ for 3 months every month in cash. This means that in terms of criteria and nominal, it has been implemented according to regulations. While the provisions regarding the distribution time there are differences, where the distribution period is 1 (one) month apart from the specified time. The regulation states that the distribution will start in April 2020 while the distribution will take place in May 2020, this means that in terms of timing, the distribution has not been implemented according to existing regulations.

Keywords: Implementation, Policy, Direct Village Fund Cash Assistance

\section{PENDAHULUAN}

Kemiskinan merupakan permasalahan yang terjadi hampir diseluruh belahan dunia terutama negara dengan kepadatan penduduk yang tinggi dan menjadi perhatian banyak orang. Kemiskinan menyebabkan seseorang atausekelompok orang tidak mampu dalam memenuhi hak-hak dasarnya seperti tidakterpenuhinya kebutuhan pangan, kesehatan, pendidikan, pekerjaan perumahan, airbersih, sumber daya alam dan lingkungan (Usman, 2006). Pemerintah selalu mencari alternatif untuk pemecahan masalah-masalah yang terjadi dengan harapan dapat mencapai kesejahteraan seluruh masyarakat.

Pada bulan Maret tahun 2019 jumlah masyarakat miskin di Indonesia sebanyak 25,14 juta orang dengan presentase 9,41\% dan pada bulan Maret 2020 angka kemiskinan mengalami peningkatan menjadi 26,47 juta orang dengan presentase 9,78\%. Artinya selama 1 (satu) tahun terakhir jumlah masyarakat miskin di Indonesia mengalami peningkatan sebanyak 1,28 juta orang dengan presentase $0,37 \%$. Hal ini tidak dapat dipungkiri juga dipengaruhi oleh pandemi global yang melanda Indonesia.

Dalam penanganan kemiskinan jauh sebelum itu pemerintah telah melakukan upaya untuk menangani masalah ini dengan program jaminan sosial. Strategi dan kebijakan yang dipilih sebagai upaya mencapai kesejahteraan bersama, diharapkan mampu mengatasi kesenjangan dalam masyarakat sehingga tidak ada perbandingan yang mencolok antara satu kelompok masyarakat yang lebih sejahtera dengan kelompok masyarakat yang lain. 


\section{P-ISSN $2580-7781$}

E-ISSN $2615-3238$

Kemunculan sebuah virus dari China pada awal tahun 2020 menggemparkan dunia yang merebak pertama kali di Wuhan. Kemudian diketahui sebagai virus Coronaatau dalam bahasa ilmiah kedokterannya disebut CoronaVirus Disease 2019 penyakit menularyang mengakibatkan infeksi pernafasan, mulai dari gejala ringan seperti flu hingga infeksi paru-paru seperti pneumonia.

Corona Virus Disease-2019 (Covid-19) resmi dinyatakan masuk ke Indonesia pada Maret 2020. Sejak saat itu, penyebaran virus makin meluas dan berkembang cepat hampir di seluruh daerah. Per tanggal 1 April 2020, total jumlah pasien positif Covid-19 di Indonesia menjadi sebanyak 1.677 orang. Dari 1.677 kasus positif Covid-19 tersebut,1.417 pasien saat ini menjalani perawatan dan 103 pasien dinyatakan berhasil sembuh dari penyakit Covid-19. Sementara itu, WNI di luar negeri juga sudah terdampak Corona dengan jumlah korban sebanyak 133 WNI yang positif terinfeksi Covid-19 (Idhom,2020).

Akibat kasus Corona ini, pemerintah Indonesia mulai memberlakukan berbagai kebijakan seperti Pembatasan Sosial Berskala Bersar (PSBB) yang didalamnya terkait dengan social distancing, bekerja dari rumah bagi pegawai, belajar di rumah, memberlakukan pembatasan wilayah, membangun RS khusus untuk penanganan Covid-19, penutupan berbagai tempat publik seperti tempat wisata. Dengan adanya kebijakan pemerintah ini serta situasi yang semakin genting, tentunya memberikan dampak bagi masyarakat, baik masyarakat menengah kebawah hingga kalangan elit. Berbagai masalah sosial ekonomi muncul dan dampaknya langsung terasa oleh masyarakat (Kelas Pintar, 2020).

Untuk melindungi masyarakat miskin dan rentan dari dampak pandemi Covid-19 pemerintah telah merancang berbagai kebijakan baru dalam rangka menekan penyebaran dan penanganan virus ini. Salah satu kebijakan yang dikeluarkan pemerintah yakni dengan diterbitkannya Undang-Undang Nomor 1 Tahun 2020 tentang Kebijakan Keuangan Negara dan Stabilitas Sistem Keuangan untuk Penanganan Pandemi Corona Virus Disease (Covid-19) dan/atau Dalam Rangka Menghadapi Ancaman yang Membahayakan Perekonomian Nasional dan/atau Stabilitas Sistem Keuangan menjadi Undang-Undang. 


\section{P-ISSN 2580 - 7781}

E-ISSN $2615-3238$

Selain itu pemerintah memperluas Jaring Pengaman Sosial (JPS) termasuk yang tertuang dalam Peraturan Menteri Desa PDTT Nomor 6 Tahun 2020 tentang Perubahan Peraturan Menteri Desa PDTT Nomor 11 Tahun 2019 tentang Prioritas Penggunaan Dana Desa yang diantaranya terkait penyediaan Bantuan Langsung Tunai yang bersumber dari Dana Desa (BLT Dana Desa). Dalam rangka melancarkan pelaksanaan BLT-Dana Desa ini berbagai kebijakan lain telah diterbitkan diantaranya adalah Instruksi Menteri Dalam Negeri Nomor 3 Tahun 2020 tentang Penanggulangan Covid-19 di Desa Melalui Anggaran Pendapatan dan Belanja Desa dan Peraturan Menteri Keuangan Nomor 40 Tahun 2020 tentang Perubahan Atas Peraturan Menteri Keuangan Nomor 205 Tahun 2019 tentang Pengelolaan Dana Desa (Buku Panduan Pendataan BLT-DD).

Bantuan Langsung Tunai Dana Desa (BLT-DD) merupakan bantuan uang yang langsung diberikan secara tunai kepada masyarakat yang menjadi sasaran program ini yaitu masyarakat miskin atau masyarakat dengan taraf ekonomi rendah dan rentan kesulitan dalam memenuhi kebutuhan hidup sehari-hari terutama akibat pandemi Covid-19. Salah satu persyaratan yang ditetapkan adalah keluarga miskin dan rentan yang belum menerima bantuan dari skema jaminan kesejahteraan sosial lain seperti Program Keluarga Harapan (PKH), Bantuan Pangan Non-Tunai (BPNT) dan Kartu Prakerja berhak menerima bantuan ini. Bantuan Langsung Tunai Dana Desa (BLT-Dana Desa) diberikan dengan besaran nominal Rp. 600.000 setiap bulan untuk tiga (3) bulan pada setiap keluarga miskin yang terdampak pandemi dan memenuhi kriteria yang telah ditentukan dengan sumber Dana Desa yang diterima oleh desa yang bersangkutan dengan presentase maksimal 35\%. Desa dapat menentukan sendiri secara lebih spesifik mengenai kriteria penerima dengan landasan aturan yang telah diberlakukan di daerah tersebut.

Desa Prajekan Lor merupakan salah satu desa yang berada di Kabupaten Bondowoso yang masyarakatnya juga terdampak pandemi, baik secara langsung yang artian ada beberapa warga terkonfirmasi positif Covid-19 dan terdampak secara tidak langsung. Dampak tidak langsung memukul hampir seluruh masyarakat desa dalam bidang ekonomi karena sebagian besar pendapatan warga 
menurun drastis sehingga berpengaruh pada pemenuhan kebutuhan hidup. Berdasarkan informasi dari Pemdes Prajekan Lor sebagian besar warga desa Prajekan Lor bermata pencaharian petani. Ketersediaan pupuk yang cukup langka mengakibatkan hasil pertanian tidak maksimal sehingga pendapatan petani menurun. Juga para pedagang, kuli dan buruh serta pekerja serabutan yang jumlah pendapatannya sangat terdampak dengan kebijakan yang dikeluarkan pemerintah untuk menangani Covid-19, bahkan tidak mampu mencukupi kebutuhan seharihari.

Distribusi bantuan sosial di Desa Prajekan Lor Kabupaten Bondowoso telah dilakukan dan dijalankan. Hal tersebut tentunya tidak terlepas dari peran pemimpin dan pihak-pihak terkait dalam upaya pendataan dan penyaluran kepada calon penerima manfaat Bantuan Langsung Tunai Dana Desa (BLT DD). Polemik yang terjadi di Desa Prajekan Lor seperti permasalahan yang umumnya terjadi di banyak desa. Setelah calon penerima BLT DD ditetapkan dan kemudian penyaluran dilakukan, protes dari beberapa masyarakat terjadi. Mereka merasa dirinya layak untuk mendapatkan bantuan namun tidak terdaftar sebagai penerima manfaat bantuan sosial tersebut.

Setelah menghimpun informasi dari informan yang terlibat dalam pelaksanaan Bantuan Langsung Tunai Dana Desa diperoleh informasi mengenai fenomena yang menarik untuk diteliti, diantaranya keterlambatan penyaluran dan penerima yang kurang dari sasaran. Penyaluran petama pada bulan Mei, sedangkan dalam Peraturan Kepala Desa Prajekan LorNomor188 tentang Penetapan Penerima Bantuan Langsung Tunai Dana Desa masa penyaluran terhitung sejak bulan April hal ini tentu tidak sesuai dengan peraturan. Jumlah penerima BLT hanya sebanyak 45 KPM dari 90-an usulan nama calon. Besaran nominal yang disalurkan untuk tiap tahapnya yakni Rp 600.000 perKPM tiap bulan selama 3 (tiga) bulan perKPM. Dana Desa yang diterima oleh Desa Prajekan Lor sebesar Rp 848.906.000. Artinya dana yang dianggarkan untuk kebutuhan BLT sekitar 10\% dari DD yang diterima. Berdasarkan latang belakang tersebut maka rumusan masalah dalam penelitian ini adalah "Bagaimana Implementasi Program Bantuan Langsung Tunai Dana Desa Sebagai Upaya 
P-ISSN 2580 - 7781

E-ISSN $2615-3238$

Penanganan Pandemic Corona Virus Disease (Covid-19) Di Desa Prajekan Lor Kabupaten Bondowoso?".

\section{METODE PENELITIAN}

Metode penelitian ini adalahkualitatif dimana peneliti mencari informasi dan data dari informan yang telah ditentukan. Informan-informan tersebut adalah orang yang dipilih dengan sengaja berdasarkan kriteria tertentu. Dalam hal ini informan yang dipilih adalah orang yang terlibat dalam penyelenggaraan Program Bantuan Langsung Tunai Dana Desa di Desa Prajekan Lor sebanyak 12 orang dengan perincian Kepala Desa,Kasi Kesos Pemdes Prajekan Lor, Ketua BPD, 1 Orang Ketua RW dari masing-masing dusun (3 dusun), 2 orang penerima program dari masing-masing dusun. Pengumpulan data dilakukan dengan beberapa cara yakni:

\section{Observasi (Pengamatan)}

2. Interview (Wawancara)

3. Teknik dokumentasi

4. Studi Pustaka

Analisis data yang digunakan dalam penelitian ini adalah analisis interaktif. Menurut Moleong (2004), analisis data adalah proses mengorganisasikan dan mengurutkan data kedalam pola, kategori, dan satuan uraian dasar sehingga dapat ditemukan tema dan tempat dirumuskan hipotesis kerja seperti yang disarankan oleh data. Beberapa tahapan model analisis menurut Miles dan Huberman (2007) melalui empat tahap, yakni pengumpulan data, reduksi data, penyajian data dan penarikan kesimpulan.

Uji Keabsahan data dilakukan untuk membuktikan apakah penelitian yang dilakukan benar-benar merupakan penelitian ilmiah sekaligus untuk menguji data yang diperoleh. Menurut Sugiyono (2007) Uji Keabsahan data dilakukan dengan:

\section{Derajat Kepercayaan (Credibility)}

2. Keteralihan (Transferability)

3. Kebergantungan (Dependability)

4. Kepastian (Confimability) 


\section{HASIL PENELITIAN DAN PEMBAHASAN}

Program Bantuan Langsung Tunai Dana Desa merupakan bantuan keuangan yang bersumber dari Dana Desa dan ditujukan bagi masyarakat miskin dan rentan yang kesulitan dalam memenuhi kebutuhan hidupnya sehari-hari terutama akibat wabah Covid-19.Kriteria yang ditentukan sebagai penerima program adalah masyarakat miskin dan rentan yang belum menerima bantuan dari skema jaminan kesejahteraan sosial lain seperti Program Keluarga Harapan (PKH), Bantuan Pangan Non-Tunai (BPNT) dan Kartu Prakerja berhak menerima bantuan ini.

Tiap desa dapat menentukan sendiri siapa yang akan ditetapkan menjadi penerima berdasarkan kriteria. Besaran dana yang akan disalurkan ditentukan dari Dana Desa yang diterima oleh desa yang bersangkutan. Berdasarkan informasi dari Sekdes Prajekan Lor menerima Dana Desa sejumlah Rp 848.906.000,00 dengan anggaran untuk Program BLT maksimal sebesar 25\% dari DD yang diterima. Dalam Peraturan Kepala Desa Prajekan LorNomor188 Tahun 2020 Tentang Penetapan Penerima Bantuan Langsung Tunai Dana Desa diuraikan mengenai kriteria calon KPM, nominal serta jangka waktu penyaluran BLT DD.

\section{A. Kriteria}

Kriteria yang ditentukan sebagai penerima Bantuan Langsung Tunai Dana Desa di Desa Prajekan Lor adalah keluarga miskin non program keluarga harapan $(\mathrm{PKH})$ atau Bantuan Pangan Non Tunai (BPNT) yang kehilangan Mata Pencaharian, Belum Terdata dan mempunyai anggota keluarga yang rentan sakit menahun/kronis yang terdampak secara langsung ataupun tidak langsung Covid19, meliputi :

1. Masyarakat miskin;

2. Lansia;

3. Wanita rawan sosial (janda/jompo);

4. Masyarakat yang mengalami PHK:

1) Karyawan Swasta

2) Buruh pabrik. 


\section{P-ISSN 2580 - 7781}

E-ISSN 2615 - 3238

5. Masyarakat terdampak Covid-19:

1) Isolasi di Rumah Sakit;

2) Isolasi Mandiri;

3) Karantina Mandiri

Kriteria tersebut digunakan sebagaiacuan usulan calon KPM, setelah namanama diusulkan oleh berbagai pihak yang mana dalam hal ini adalah Tim relawan, RT maupun RW kemudian akan dimusdeskan terlebih dahulu untuk menentukan penetapan penerima.

Dari wawancara yang telah dilakukan diperoleh informasi bahwa penerima BLTDD di Desa Prajekan Lor telah memenuhi kriteria yang ditentukan berdasarkan Peraturan Kepala Desa Prajekan Lor Nomor188 Tahun 2020 Tentang Penetapan Penerima Bantuan Langsung Tunai Dana Desa yang mengacu pada Permendes PDTT. Pengusulan nama calon dilakukan oleh ketua RW masingmasing wilayah yang kemudian nama-nama tersebut diverifikasi dan dimusdeskan untuk menetapkan penerima bantuan. Penerima bantuan langsung tunai merupakan masyarakat miskin terdampak Covid-19 (positif) yang tidak mendapatkan bantuan sosial lainnya seperti PKH, BPNT dan Prakerja serta kehilangan mata pencahariannya karena pandemiCovid-19.

\section{Nominal}

Sumber dana BLT DD berasal dari dana desa dengan ketentuan yang telah diatur oleh Permendes PDTT No 06 Tahun 2020 tentang Prioritas Penggunaan Dana Desa. Besaran nominal tiap bantuan sosial yang diberikan tidak sama, besaran BLT DD yang diberikan kepada penerima merupakan dana desa yang diprioritaskan beberapa persen untuk bantuan. Dalam aturan tertulis presentase maksimal yang dapat digunakan oleh desa untuk BLT tergantung dari besaran DD yang diterima. Prajekan Lor merupakan desa yang menerima Dana Desa sebesar Rp 848.906.000 dapat menggunakan dana desa untuk kebutuhan BLT maksimal $30 \%$ dari DD yang diterima.

Besaran yang diberikan kepada masing-masing penerima dalam tiap tahap mengacu pada Peraturan Kepala Desa Pajekan Lor Nomor 188 Tahun 2020 


\section{P-ISSN 2580 - 7781}

E-ISSN $2615-3238$

Tentang Penetapan Penerima Bantuan Langsung Tunai Dana Desa yang disebutkan secara jelas adalah sebesar Rp 600.000 selama 3 bulan tunai.

Dari hasil wawancara yang telah dilakukan dapat di simpulkan bahwa nominal yang diberikan dalam Bantuan Langsung Tunai DD sesuai dengan Peraturan yang telah ditetapkan, yakni sebesar Rp 600.000 per KPM selama 3 bulan. Anggaran BLTDD bersumber dari dana desa, melihat dari jumlah penerima BLT sebanyak 45 orang, presentase dana yang dianggarkan sekitar 10\% dari DD yang diterima.

3. Waktu

Bantuan sosial diberikan dalam kurun waktu tertentu sesuai dengan aturan yang telah ditetapkan. Berdasarkan Peraturan Kepala Desa Nomor 188 Tahun 2020 tentang Penetapan Penerima BLT DD yang menjadi acuan dasar dalam penyelenggaraan program Bantuan Langsung Tunai Dana Desa di Desa Prajekan Lor waktu yang ditentukan terhitung sejak April tahun 2020 diberikan tiap bulan selama 3 bulan.

Berdasarkan hasil wawancara yang telah dilakukan peneliti menemukan perbedaan masa penyaluran pada pelaksanaan dan peraturan yang telah ditetapkan. Dalam Peraturan Kepala Desa Prajekan Lor terhitung masa penyaluran sejak bulan April 2020 namun penyaluran tahap pertama baru dilaksanakan pada bulan Mei 2020. Berdasarkan klarifikasi dengan pelaksana program keterlambatan penyaluran terjadi akibat pencairan Dana Desa yang terlambat.

\section{KESIMPULAN}

Dari hasil penelitian dilapangan dapat disimpulkan bahwa Program Bantuan Langsung Tunai Dana Desa di Desa Prajekan Lor dengan ketentuan yang telah diatur dalam Peraturan Kepala Desa Nomor 188 Tahun 2020 tentang penetapan Penerima BLT DD antara lain:

\section{Kriteria}

Masyarakat penerima Bansos ini telah sesuai dengan syarat yang telah ditetapkan, kriteria yang diprioritaskan diantaranya adalah masyarakat miskin yang belum menerima bantuan sosial lainnya, terdampak langsung yang artinya 


\section{P-ISSN $2580-7781$}

E-ISSN 2615 - 3238

positif Covid-19 serta terdampak tidak langsung artinya mereka hanya memiliki sumber penghasilan tunggal dan kehilangan sumber penghasilan tersebut akibat pandemi. Dalam penetapan penerima ada polemikdalam masyarakat akibat ketidakpuasan atas penetapan tersebut. Pemdes berupaya mengkomunikasikan hal ini dengan berbagai pihak RT dan RW untuk memberikan pengertian kepada masyarakat. Maka dapat disimpulkan ketentuan mengenai kriteria penerima telah terimplementasi sesuai Peraturan Kepala Desa Prajekan Lor yang menjadi acuan pelaksanaan program ini.

2. Nominal

Nominal yang diberikan dalam BLTDD sebesar Rp 600.000 secara tunai kepada yang bersangkutan selama 3 bulan berturut-turut. Maka dapat disimpulkan bahwa dalam ketentuan nominal telah terimplementasi sesuai dengan Peraturan Kepala Desa Prajekan Lor yang menjadi acuan pelaksanaan BLTDD di Desa Prajekan Lor.

\section{Waktu Penyaluran}

Penyaluran BLTDD dilakukan pada bulan Mei 2020 sedangkan dalam Peraturan tertulis masa penyaluran terhitung sejak bulan April 2020. Maka dapat disimpulkan bahwa ketentuan mengenai masa penyaluran belum terimplementasi sesuai aturan karena penyaluran terlambat 1 (satu) bulan dari waktu yang telah ditentukan. Hal ini disebabkan karena terlambatnya pencairan Dana Desa yang diterima oleh Desa Prajekan Lor.

\section{DAFTAR PUSTAKA}

Addi M. Idhom. 2020. Update Corona 1 April: Sebaran 1.677 Kasus di 32 Provinsi Indonesia. [Online]. Tersedia pada :https://tirto.id/updatecorona-1-april-sebaran-1677-kasus-di-32-provinsi-indonesia-eKdu.[20 Januari 2021]

Kelas Pintar. 2020. Virus Corona Jadi Pandemi Global. [Online]. Tersedia pada: https://www.kelaspintar.id/blog/edutech/virus-corona-jadi-pandemiglobal-apa-sih-pengertian-pandemi-3854/

Miles, Mattew B dan Amichael Huberman. 2007. Analisis Data Kualitatif Buku Sumber tentang Metode-Metode Baru. Terjemahan Tjetjep Rohendi Rohisi. Jakarta: Universitas Indonesia 
Moleong Lexy J. 2004.Metodologi Penelitian Kualitatif. Bandung: Remaja Rosdakarya.

Panduan Pendataan Bantuan Langsung Tunai Dana Desa (BLT-Dana Desa) Juni 2020. Kementrian Desa, Pembangunan Daerah Tertinggal dan Transmigrasi

Sugiyono. 2007. Metode Penelitian Kuantitatif Kualitatif dan R\&D. Bandung: Alfabeta

Usman Sunyoto. 2006. Pembangunan dan Pemberdayaan Masyarakat. Yogyakarta: Pustaka Pelajar. 